Павел РУДЈАКОВ

Институт за светску историју Националне Академије наука Украјине, Кијев
Оригинални научни рад

Примљен: 28. 12. 2020.

Прихваћен: 25. 2. 2021.

\title{
О РЕЦЕПЦИЈИ СРПСКЕ КЬИЖЕВНОСТИ У УКРАЈИНСКОЈ АКАДЕМСКОЈ НАУЦИ У ДРУГОЈ ПОЛОВИНИ ХХ ВЕКА
}

\begin{abstract}
Рецепција српске књижевности, фолклора, културе и рефлекси њихове историје у украјинској културној средини, укључујући њен научни сегмент, имају давну традицију. Преглед свега оног што је већ било урађено или би евентуално могло да буде увршћено у ову причу није предмет овог текста, па бих у вези с традицијом на основу које се формирала и развијала украјинска академска наука у другој половини XX века споменуо само једну епизоду. Ради се о раздобљу између 1830-их и 1860-их година, када су украјински представници постали активни учесници процеса стварања првих центара предавања и проучавања славистичких предмета у Царској Русији.
\end{abstract}

Кључне речи: рецепција, српска књижевност, украјинска академска наука, 20. век.

Рецепција српске књижевности, фолклора, културе и рефлекси њихове историје у украјинској културној средини, укључујући њен научни сегмент, имају давну традицију. Један од оних који је овом послу дао велики допринос био је Осип Бодјански (1808-1877), други - Измајил Срезњевски (1812-1880). Њих двојица су заједно са Петром Прејсом (1810-1846) и Виктором Григоровичем (1815-1876) постали први руски слависти које је царска влада, после ступања на снагу 1835. године у Русији новог универзитетског статута, којим је било предвиђено оснивање катедра „за историју и књижевности словенских наречја" на универзитетима, сврсисходно припремила за рад на оснивању првих катедра за славистику на универзитетима Москве, Санкт Петербурга, Казања и Харкова. Кијев је из списка изостао, иако је баш тих година осниван универзитет Светог Владимира (данас је то универзитет „Тарас Шевченко”). Слична катедра није била основана на њему због страха руских власти од раста пољског утицаја у региону и у круговима локалне духовне елите. Славистика је већ у то доба носила на себи печат идеологије и државне политике.

О. Бодјански, који је на студије у Москву дошао из Полтавског краја у Украјини, био је упућен у групу првих слависта Московског универзите- 
та, где је претходно дипломирао (1834), магистрирао (1837), па после дужег (од 1837. до 1841. године) боравка у иностранству, у словенским крајевима Аустрије, Турске, Италије, Немачке, Прусије, Пољске (1840. године посетио је Београд), више година радио као професор славистике. Магистарски рад Бодјанског био је посвећен народном песништву словенских племена. У једном од његових дела ради се о српској усменој поезији, коју је аутор већ у том периоду јако добро познавао. Једна у низу заслуга Бодјанског јесте да је баш он почео рецепцију српске књижевности и културе за научну и ширу јавност у оквиру не само индивидуалне активности, већ и на институционалној основи, у име једног универзитета и посебне специјализоване катедре.

Међу свим оним што је О. Бодјански успео да уради на подручју славистичких студија у вези са нашом темом најзанимљивија су два текста: „Српска књижевност” и „Нацрт историје Дубровника”. Први представља нацрт већег дела, које аутор, нажалост, није успео никад да приведе крају. Овде је наведена уопштена шема организације грађе: „А. Књижевност Срба грчке вероисповести”, „Б. Језик и дела Срба католичке вероисповести”. У сваком од њих има мањих поглавља. У првом су то: „1. Судбина српског језика и књижевности”, „2. Преглед новије српске књижевности”. Други је потпуно готов текст написан на веома високом научном нивоу на основу више научних и других извора, који, нажалост, још увек није објављен па остаје доступан само у рукопису у архиву научника.

И. Срезњевски је боравио у словенским крајевима током 1839-1842. године. Његов је научни рад после повратка кући био углавном усмерен на лингвистику и фолклор, а не на књижевност. Посебну пажњу у контексту нашег излагања привлачи његово блиско познанство и стални контакти са Вуком Караџићем, којега је упознао у Србији. Ову је тему изврсно и готово исцрпно обрадио В. Вулетић у чланку из 1964. год. „Срезњевски и Вук”.

Рецепција српске књижевности и културе у Русији уз стално и значајно учешће Украјинаца са релативно великим одјеком у украјинској културној средини успешно, иако не увек у истом обиму и с једнаким квалитетом, наставља се у наредним историјским раздобљима све до краја Другог светског рата 1945. године, када долази до, у правом смислу те речи, продора у домену организације проучавања славистике па и србистике као једног од њених саставних дела. Ускоро после тога славистичке студије у Совјетском Савезу, добијајући чврсту државну подршку, концентришу се у низу нових посебних институција у оквиру Академије наука СССР-а и неких од савезних република, међу њима и Украјине, као и Министарства просвете.

У Москви је 1946. године основан Институт за славистичке студије АН СССР (Институт славяноведения; од 1968. - Институт за славистичке и балканолошке студије; Институт славяноведения и балканистики). У Кијеву је 1947. године формиран посебан одсек за општу историју и историју Словена у Историјском институту Академије наука Украјине. Нешто касније - 1956. године - одсек за славистичке и балканолошке студије почео је да функционише у још једној од украјинских академских установа - Институту за књижевност „Тарас Шевченко”. Наредних су година сличним путем у организа- 
цији студија из славистике кренули Институт за језик и Институт за фолклор и етнографију. Ови су, на први поглед чисто формални, кораци извршили веома јак позитиван утицај на стање ствари у украјинској славистици. Захваљујући њима проучавање историје, књижевности, језика, фолклора, култура словенских народа у Украјини кренуло је са знатно већом активношћу него раније па је донело и знатно више практичних резултата релативно високог научног нивоа, који су имали широк и значајан друштвено-политички одјек.

У новооснованом одсеку за славистичке и балканолошке студије Института за књижевност „Тарас Шевченко” током неколико првих година србистика није била заступљена због одсуства стручњака и јако неповољног политичког контекста какав је постојао током 1948-1955. године због конфликта државног врха СССР-а и Југославије. Стање је почело да се мења почетком шездесетих година прошлог века, па се од тог тренутка све до краја XX века развој србистике кретао претежно узлазном путањом и у погледу пораста броја истраживања из српске књижевности и из аспекта проширивања заступљених лица и појава, и у, што је најбитније, порасту њиховог квалитета. Као веома важну и значајну последицу концентрације студија славистике и србистике у Академији наука треба да поменемо чињеницу да су академски институти постали лидери проучавања и популаризације словенских језика, књижевности, историје, културе. Институт „Тарас Шевченко” заузео је такво место и преузео на себе такву улогу у својој бранши.

Према подели интересних сфера научних истраживања у оквиру Академије наука СССР-а и њених друштвених института одсек за славистику и балканистику Института „Тарас Шевченко” у Кијеву добио је задатак да се усмери на проучавање међусловенских књижевних веза у ширем значењу тог појма. У тај су круг, наравно, улазиле и украјинско-српске везе, на које је и била усредсређена главна пажња научника.

У почетном периоду, док су други академски аутори већ објављивали зборнике научних радова у жанру књижевних портрета, као што су „Савремени пољски писци” (1960), „Савремени бугарски писци” (1962), „Савремени писци Чехословачке” (1963), аутори који су се бавили историјом српске књижевности и књижевности других народа Југославије једва да су могли да објаве неке приказе на тему украјинско-српских и српско-украјинских књижевних веза у серијским издањима под насловом „Међусловенски књижевни узајамни односи” (изашло је три књиге током 1958-1963. године) и „Словенска историја књижевности и фолклористика” (четири књиге током 1965-1968. године). Веома симптоматично је да у првој књизи прве серије уопште није било српских материјала јер уредници нису успели да пронађу ауторе који би могли да их напишу. Током наредних двадесетак година посао је полако кренуо набоље. Не ради се, наравно, о томе да су одмах постигнути неки мање-више озбиљни резултати, услови за такав развој догађаја нису још били створени, али је од нарочите важности било појављивање српских тема у арсеналу украјинске академске науке о књижевности. 
У Украјини је средином XX века у погледу рецепције нешто више среће од књижевности имао српски фолклор. Од 1958. године на Институту за фолклор, етнографију и историју уметности „Максим Риљски” покренуте су постдипломске студије управо за српски фолклор. Први постдипломац на овом смеру био је Михајло Гуцј, који је 1968. године у облику посебне књиге објавио свој научни рад припремљен током студија - „Српскохрватска народна песма у Украјини”. У трећој књизи „Међусловенских књижевних узајамних односа” (1963), успут речено, био је објављен његов чланак „Мало познати преводи српских народних песама на украјински језик”. Зањимљиво је да је као ментор М. Гуцја био приморан да ради професор Николај Кравцов из Москве, који је од 1947. године био научни сарадник у Институту за славистику, а од 1960. године још и управник катедре за усмено народно стваралаштво на Московском универзитету „Михајло Ломоносов”. У Кијеву у то време није било никога ко би био у стању да обавља ту функцију, и формално, и суштински.

Период квантитативне акумулације научних расправа, чланака, есеја, прегледа, библиографија везаних за историју српске књижевности потрајао je до средине осамдесетих година XX века. Након тога процес њене рецепције добио је нови подстицај и дао прве озбиљније резултате. Три су фактора, углавном, била у питању. Прво - био је покренут важан и велики научни пројекат „Украјинска књижевност у општесловенском и светском књижевном контексту”, у којем је српска књижевност заједно са украјинско-српским и српско-украјинским везама заузела посебно место. Друго - српска је грађа постала равноправни саставни део књижевноисторијских и делимично књижевнотеоријских расправа које су обухватале више словенских књижевности и проблеме општег карактера и садржаја. Најзад, треће - нова је генерација академских аутора у Украјини, мање се обазирући на претходни тренд усмерен првенствено на проучавање књижевних веза и излазећи из његових оквира, почела активно да се бави истраживањем српске прозе, углавном историјског романа, као и романа других врста.

Издање „Украјинска књижевност у општесловенском и светском књижевном контексту" направљено је у хронолошком редоследу - од најстаријих времена до последње четвртине XX века - и састоји се од пет књига: три прве чине научни текстови, две остале - библиографија превода, критичких расправа и других облика узајамне рецепције украјинске књижевности и других словенских (прве две књиге) и несловенских (књига трећа) књижевности (прва књига објављена је 1987, последња - 1994. године).

Српска књижевност заступљена је у више поглавља, између осталог и у онима у којима се ради о темама везаним за све словенске књижевности, као на пример: „Од старих времена до средине XVIII века”, „Од краја XVIII до средине XIX века”, „Тарас Шевченко и словенске књижевности” и др. Низ је поглавља у првој и другој књизи директно посвећен рецепцији српске књижевности на украјинском језичком подручју, а исто тако и свакојаким везама између српске и украјинске књижевности, укључујући и контакте, и типолошке сличности, и везе условљене заједничким пореклом (генетске), па 
и различите њихове комбинације. Како у првом, тако је и другом случају украјинска публика добила пунију, систематски обрађену и представљену, стављену у различите контексте слику српских књижевних збивања, сазнала је више имена српских писаца и назива њихових дела, назива српске књижевне периодике, књижевно-културних институција и слично, добила је могућност да сагледа српску књижевност у развоју, као процес, па да га упореди са књижевним процесом у украјинским земљама.

Кад говоримо о томе да је низ украјинских научника почео да користи грађу из историје српске књижевности у истраживањима теоријског, концептуалног или општесловенског карактера, требало би да у првом реду споменемо академика Академије наука Украјине Григорија Вервеса, дугогодишњег (од 1958. године) управника одсека за славистичке и балканолошке студије на Институту „Тарас Шевченко”. Иначе стручњак из историје пољске књижевности, Г. Вервес је у познијим годинама почео да осмишља пољске писце, њихова дела и књижевне појаве у контексту других словенских књижевности, па је и српска књижевност у овом његовом подухвату заузела веома запажено, веома почасно место. У својим научним радовима Г. Вервес је користио претежно дескриптивну и компаративну методу, тако да је својим читаоцима пружио у исто време и обичан опис једног предмета, и његову књижевно-историјску анализу, и - као допуну - његов приказ у окружењу сличних предмета из домена других словенских књижевности. Што се тиче примера и паралела из српске књижевности, њих је највише, они су најпредметнији и најсадржајнији у књизи „У интернационалним књижевним везама. Питање контекста" (1976, друго допуњено издање 1983).

Године 1990. у Кијеву је објављен зборник научних радова из историје књижевности словенских и других социјалистичких земаља „На новим орбитама”. Српска грађа је присутна у оба уводна чланка, који разматрају питања општег карактера, присутна у различитим националним књижевностима. Аутор првог од њих, Г. Вервес, међу неколико других најистакнутијих словенских писаца XX века спомиње И. Андрића, ауторка другог, Валерија Ведина, активно и плодно користи у својој анализи дела М. Лалића, Б. Ћопића, Д. Ћосића, М. Селимовића, Е. Коша, Д. Михајловића као и неке краће рефлексије које се тичу одређених појава, прилика, тенденција у српској књижевности друге половине ХХ века.

Значајан део радова (три од укупно девет) у зборнику директно је посвећен темама из најновије српске прозе. Када се овај квантитативни пораст упореди с претходним стањем, када је један „српски” текст у академским издањима у Украјини долазио, у најмању руку, на тридесетак па чак и више од тога „несрпских”, биће јасно да је рецепција српске књижевности у украјинској академској науци у овом периоду добила нов јак подстицај.

Прва по реду међу ауторима чланака о српској књижевности, Ана Једлинска, на примерима прозних дела представника старије и млађе генерације српских писаца А. Исаковића, М. Булатовића, Д. Михајловића, Б. Пекића, С. Селенића, М. Ковача размишља о позицијама реализма у српској прози седамдесетих и осамдесетих година XX века. Друга ауторка, Надежда Непо- 
рожња, анализирајући романе И. Андрића, М. Црњанског, М. Селимовића, Б. Петровића, М. Маркова, као и низа других аутора, говори о проблему традиционалног и новог у српском историјском роману. Павел Рудјаков, расправљајући о југословенском роману најновијег времена, већину грађе узима баш из српске књижевности, између осталог, дајући краћи приказ романа „Нож” В. Драшковића, као и низа других дела која у оно време нису била позната украјинској јавности.

Као још један од облика рецепције српске књижевности у Украјини требало би да споменем низ енциклопедијских чланака о српским писцима у фундаменталном академском издању „Украјинска књижевна енциклопедија” у пет књига (1988-1995), оствареном у Институту за књижевност „Тарас Шевченко" у време када је његов директор био академик Академије наука Украјине Игор Дзеверин, који је био председник научног одбора издања. За разлику од горепоменутог зборника „На новим орбитама” и од низа других издања, у којима је била заступљена нова и најновија српска књижевност, „Енциклопедија” је упознала Украјинце са представницима претходних генерација српских писаца, почевши од Вука Караџића и П. П. Његоша па преко Б. Радичевића, Л. Костића, Л. Лазаревића, М. Глишића до писаца и песника XX века - И. Андрића, М. Селимовића и др. На тај је начин представа о српској књижевности у Украјини била допуњена, знатно проширена, па је добила систематски изглед.

Свој је допринос рецепцији српске књижевности у украјинској академској науци дао и аутор ових редака, који је као научни сарадник, а у једном краћем периоду и научни секретар на Институту „Тарас Шевченко” био задужен управо за српску књижевност и књижевност других народа бивше Југославије. У периоду од 1986. до 1990. написао сам и објавио у колективним научним издањима одсека за славистику, а исто тако и у неколико бројева научног часописа „Совјетска историја књижевности” („Радянське літературознавство”), који је иначе упоредо са књижевно-уметничким часописом „Свемир” („Всесвіт”) био једна од главних трибина рецепције српске књижевности и њене историје, низ чланака о српском историјском роману, као и о роману о Народно-ослободилачкој борби 1941-1945. године.

На предлог Одељења за историју Српске академије наука и уметности 1991. године припремио сам за штампу украјински превод „Србије на Истоку” С. Марковића, који је био 1995. год. и објављен у осмој књизи његових „Целокупних дела” у издању САНУ. Превод „Србије на Истоку” на украјински језик сачинио је Теофан Василевски седамдесетих година XIX века. Рукопис овог текста чува се у Институту за књижевност „Тарас Шевченко”. Василевски је украјински публициста из круга познатог украјинског писца Ивана Франка, у чијем је архиву превод Марковићевог дела и сачуван. Заједно са другим сународницима он је као добровољац био учесник у устанку против Турака 1875-1876. године. Током 1875-1876, 1878-1881. године у часописима „Правда”, „Світ”, „Дзвін”, „Молот”, „Громадський друг” Василевски је штампао фељтоне о Србима, српским народним обичајима, српској историји, животу Срба под турском влашћу и оружаној борби против њих. И. 
Франко је 1905. године објавио ове прилоге у посебном издању под насловом „Записи једног Украјинца о боравку међу Јужним Словенима” уз свој увод.

Године 1993. у издавачкој кући Академије наука Украјине „Научна мисао” („Наукова думка”) у Кијеву изашла је из штампе моја књига „Историја као роман”, у којој су три од четири поглавља посвећена српским писцима - И. Андрићу, М. Селимовићу, М. Црњанском (у четвртом се ради о роману „Заставе” М. Крлеже). Године 2001. она је под истим називом угледала свет на српском језику у заједничком издању београдског Завода за уџбенике и наставна средства, Вукове задужбине и Матице српске уз једну измену: уместо текста о М. Крлежи било је убачено поглавље о М. Павићу. Године 1995. на седници специјалног научног већа на истом Институту „Тарас Шевченко” одбранио сам докторску тезу на тему „Југословенски (српски и хрватски) историјски роман 40-80-их година XX века. Особености историјске концепције и наративне структуре”. Испало је да је овај „српски” докторат био у Украјини први за готово педесет година. Следећи (који је припремила и одбранила Н. Билик) је дошао двадесет и нешто година касније, поткрај 2010. године, и то не на Академији наука Украјине, него на Кијевском универзитету „Тарас Шевченко”. Академија је у међувремену, на велику жалост па и штету, дефинитивно изгубила свој лидерски положај у домену рецепције српске књижевности и њене историје у Украјини. На чело овог процеса стала је Катедра за славистику Кијевског универзитета „Тарас Шевченко”, баш тамо се појавила, ојачала и утврдила се нова генерација истраживача који се баве српском књижевношћу - О. Дзјуба, Н. Билик, О. Деркач. Свака од њих је, осим низа публикација у научној периодици, објавила и по једну књигу.

Године 2000. била је објављена још једна моја књига о српској књижевности - „Између вечности и времена: живот и дело Иве Андрића”. Тако се десило да је она постала у неку руку граница у рецепцији српске књижевности у украјинској академској науци. Након тога настала је једна дужа пауза у оквиру које се нешто ипак дешава, али опште стање ствари у овој бранши није никако боље од онога какво је владало крајем XX века.

\section{ЛИТЕРАТУРА}

Рудјаков 2000: П. Рудјаков, Између вечности и времена: живот и дело Иве Андрића, 2000.

Рудјаков 2001: П. Рудјаков, Историја као роман, Београд, Нови Сад: Завод за уџбенике и наставна средства, Вукова задужбина, Матица српска.

Стеблина Рудјакова 2009: Л. Стеблина-Рудякова, Сербістика в Київському університеті імені Тараса Шевченка, <https:/www.rastko.rs/cms/files/ books/4f25dbecf1f15> 
Pavel Rudyakov

\title{
THE RECEPTION OF THE SERBIAN LITERATURE HISTORY IN THE UKRAINIAN ACADEMIC SCHOLARSHIP IN THE LATE 20TH CENTURY
}

\begin{abstract}
Summary
The scholarly interest in other Slavic peoples outside the USSR had been rekindled after a long intermission since 1950 in Ukraine, especially in Kyiv. The establishing and developing of special institutions dedicated to the research of the Slavic languages and literatures commenced in the course of that process. The research within that field was concentrated in the Ukrainian Academy of Sciences. Special departments for Slavic studies were founded within the following academic institutes: The Shevchenko Institute of Literature, The O. O. Potebnia Institute of Linguistics, The Rylsky Institute of Art Studies, Folklore and Ethnology. The research of the Serbian literature history made its first steps in the late $50 \mathrm{~s}$ and early $60 \mathrm{~s}$ in the Institute of Literature within the studies of the history of literature of the peoples of Yugoslavia, and Ukrainian and Serbian literary connections. G. Varves, M. Golybert, T. Posudnevskaya, A. Yedlinskaya, P. Rudyakov, and others worked in those research areas during the whole period in question.
\end{abstract}

